\title{
Szemelvények a Nemzetközi Hypertonia Társaság (ISH) új hipertónia-vezérfonalából, amely tömör, közérthető és a világ minden részén használható
}

\author{
Nagy Viktor \\ SE, Általános Orvostudományi Kar, Belgyógyászati és Hematológiai Klinika, Budapest \\ Levelezési cím: \\ Dr. Nagy Viktor, SE, Általános Orvostudományi Kar, Belgyógyászati és Haematologiai Klinika, Budapest \\ 1088 Budapest, Szentkirályi u. 46. E-mail: nagy.viktor@med.semmelweis-univ.hu
}

2020. júniusban a Nemzetközi Hypertonia Társaság (ISH) új hipertónia-vezérfonalat adott ki. Az ISH-irányelvek diagnosztikai és kezelési javaslatainak stratégiái tükrözik az európai és az amerikai irányelvekét, de vannak különbségek is. Az ajánlás kiterjeszthető az egész világra, könnyen alkalmazható a szegény és természetesen a gazdag országokban is. Az ajánlás szerint a hipertóniát akkor kell kórismézni, ha a rendelőben mért vérnyomás $\geq 140 / 90$ Hgmm. Fontos, hogy az orvosok a legtöbb információt szerezzék meg a betegek terápiahűségéről, mert a nonadherencia áll leggyakrabban a rossz vérnyomáskontroll hátterében. Új, a nem gyógyszeres kezelésről szóló részben a stresszt csökkentő intézkedések (transzcendentális meditáció, jóga stb.) hangsúlyozása. A legtöbb beteg esetén a vérnyomáscsökkentő kezelés megkezdése két gyógyszer kombinációjával javasolt. A következő kezelési lépéstől kezdve megfelelő kettős vagy hármas (fix) kombinációk alkalmazásával valósítható meg az egyénre szabott antihipertenzív terápia és érhető el a kívánatos vérnyomáscélérték.

Kulcsszavak: hipertónia-vezérfonal, kivizsgálás, kezelés, adherencia

Excerpts from the International Hypertension Society (ISH) new hypertension guideline, which is concise, understandable and can be used in any part of the world

In June 2020, the International Society of Hypertension (ISH) issued a new hypertension guideline. The diagnostic and treatment recommendations strategies of the ISH guidelines reflect those issued by the European and US guidelines, but there are also some differences. The recommendation can be extended to the whole world, easy to apply in poor and, of course, rich countries. It is recommended that hypertension be diagnosed if the blood pressure in the office is $\geq 140 / 90 \mathrm{mmHg}$. It is important for physicians to obtain the most information about patients 'adherence to therapy because non-adherence is most often the underlying cause of poor blood pressure control. New in the section on nonpharmacological treatment is the emphasis on stress reduction measures (transcendental meditation, yoga, etc.). The initiation of antihypertensive therapy is suggested by dual combination in the majority of hypertensive patients. The personalized therapy can be presented by dual and triple (fixed-dose) combination on the next level of treatment level, that helps to reach blood pressure goals.

Keywords: hypertension guidelines, treatment, adherence

A kézirat 2020. 06. 15-én érkezett a szerkesztőségbe, 2020. 07. 31-én került elfogadásra. 
A Nemzetközi Hypertonia Társaság (ISH) nem kis fába vágta a fejszéjét, amikor egy olyan gyakorlati útmutatót készített a hipertónia kivizsgálásáról, kezeléséről és gondozásáról, amely a világ minden részén alkalmazható. 2020. júniusban azonos időben jelent meg a Hypertension és a Journal of Hypertension folyóiratokban az új ISH Hipertónia Ajánlás - továbbiakban ISH 2020 - (az elektronikus publikációra már május 6-án sort kerítettek) (1, 2). A bizonyítékokon alapuló optimális normákat az európai és az észak-amerikai hipertónia-irányelvek tartalmazzák $(3,4)$, ám tudomásul kell venni azt, hogy ezekben az országokban az orvosok jóval több és modernebb vizsgálathoz és gyógyszerhez férnek hozzá, mint a szegény afrikai, ázsiai és dél-amerikai országokban dolgozó kollégáik. Ezért az ISH által készített útmutató bármely kérdéskör ALAPVETŐ és OPTIMÁLIS megoldását kínálja. A szerkesztők tisztában voltak azzal, hogy több nagyon fontos javaslat nem valósítható meg ott, ahol az egészségügyi ellátórendszer szerény forrással rendelkezik. Ilyen pl. a kevés jól képzett egészségügyi szakember, a rendelőn kívüli vérnyomásmérés hiányos eszközrendszere, a hipertónia megerősítéséhez szükséges csekély számú orvosi vizit, vagy akár a több hatóanyagot tartalmazó fix dózisú kombinációs készítmények elégtelen skálája. Ezért az iránymutatás végrehajtása igen nagy kihívást jelent, ám ezzel segítheti a helyi kezdeményezéseket, ösztönözheti a gazdaságpolitikai változásokat és javíthatja az ápolás színvonalát. Tudomásul kell venni azt, hogy a szegényebb országokban lényegesen kisebb a felismert hipertóniások aránya,

1. TÁBLÁZAT. A hipertónia meghatározása különböző mérési módszerekkel az ISH 2020 alapján (*a kategóriát mindig a magasabbik érték határozza meg, kivéve az izolált szisztolés hipertóniát, amely a szisztolés értékek alapján sorolandó be, miközben a diasztolés vérnyomás mindig <90 Hgmm) $(1,2)$

\begin{tabular}{c|c|c} 
Kategória & $\begin{array}{c}\text { Szisztolés } \\
\text { vérnyomás } \\
(\mathrm{Hgmm}) *\end{array}$ & $\begin{array}{c}\text { Diasztolés } \\
\text { vérnyomás } \\
(\mathrm{Hgmm}) *\end{array}$
\end{tabular}

Rendelői vérnyomásmérés

\begin{tabular}{|l|c|c|}
\hline Normális & $<130$ és & $<85$ \\
\hline Emelkedett-normális & $130-139$ és/vagy & $85-89$ \\
\hline Hipertónia & & \\
\hline 1. fokozat & $140-159$ és/vagy & $90-99$ \\
\hline 2. fokozat & $\geq 160$ és/vagy & $\geq 100$ \\
\hline Izolált szisztolés & $\geq 140$ és & $<90$
\end{tabular}

hipertónia

24 órás ambuláns vérnyomás-monitorozással (ABPM) hipertónia

\begin{tabular}{|c|c|c|}
\hline 24 órás átlag & $\geq 130$ és/vagy & $\geq 80$ \\
\hline Nappali átlag & $\geq 135$ és/vagy & $\geq 85$ \\
\hline Éjszakai átlag & $\geq 120$ és/vagy & $\geq 70$ \\
\hline \multicolumn{3}{|c|}{ Otthoni önvérnyomásmérés (HBPM) } \\
\hline Hipertónia & $\geq 135$ és/vagy & $\geq 85$ \\
\hline
\end{tabular}

mint a gazdagabbakban (38\% vs. $68 \%$ ) ez azonban sokkal-sokkal nagyobb betegszámot jelent $(1,04$ milliárd vs. 349 millió) (5)!

Az ajánlás az orvosi munkát megkönnyítendő, nagyon praktikus táblázatokat és folyamatábrákat tartalmaz, amelyekböl több fontosabbat bemutatok és részletesebben kitérek az érdekes és tanulságos változásokat tartalmazó részletekre.

\section{A hipertónia meghatározása}

Az ISH 2020, 18 éves kor felett a hipertónia diagnózisát a rendelői, otthoni, és 24 órás vérnyomásértékek alapján az európai ajánlással megegyezően határozza meg (hipertónia: a rendelői vérnyomás $\geq 140 / 90$ Hgmm stb.), azonban az amerikaihoz hasonlóan csak két hipertóniafokozatot javasol (1. fokozat: 140-159 és/vagy /9099 Hgmm, 2. fokozat: $\geq 160$ és/vagy /100 Hgmm). Kiemeli az emelkedett-normális vérnyomás jelentőségét, hiszen e betegek mindegyikének már a nem gyógyszeres kezelésben kell(ene) részesülnie. A részleteket az 1. táblázat tartalmazza.

\section{A vérnyomás pontos mérése és az eredmény értékelése}

A vérnyomásmérés pontos szabályai általánosan ismertek, de alig tartják be őket. Emiatt nem lehet eleget hangoztatni és természetesen megtanulni/megtanítani a vérnyomásmérés szabályait. Ugyanakkor el is kell várni azok betartását a rendelőben az orvosoktól és otthon a betegektől. A vérnyomásmérés általános szabályait mutatja az 1. ábra.

\section{Alapvető}

Hipertónia diagnosztizálása és gondozása általában a rendelői vérnyomásmérésen alapul, amelynek rögzített, szigorúan betartandó protokollja van. A vérnyomás szintjétől függően maximum 1 hónap alatt 3-4 rendelői vérnyomásméréssel kell megerősíteni a diagnózist. Azonban egy vizit is elegendő, ha a vérnyomás $\geq 180 / 110 \mathrm{Hgmm}$ és valamilyen szív-ér rendszeri $(\mathrm{CV})$ betegség is észlelhető. Ha ez lehetséges, akkor rendelőn kívüli vérnyomásmérést is kell végezni.

\section{Optimális}

Rendelőben a vérnyomásmérés mindkét karon történjen, lehetőleg azonos időben, a további vérnyomásméréseket azon a karon kell végezni, ahol magasabb értéket mértek, azonban ha a különbség >20 Hgmm, akkor további vizsgálatokra van szükség. A vérnyomást a felállást követő 1. és 3 . percben is meg kell mérni, ez különösen fontos idősekben és cukorbetegekben. Nagy jelentőségű a rendelőben végzett felügyelet nélküli és a rendelőn kívül végzett önmérés és 


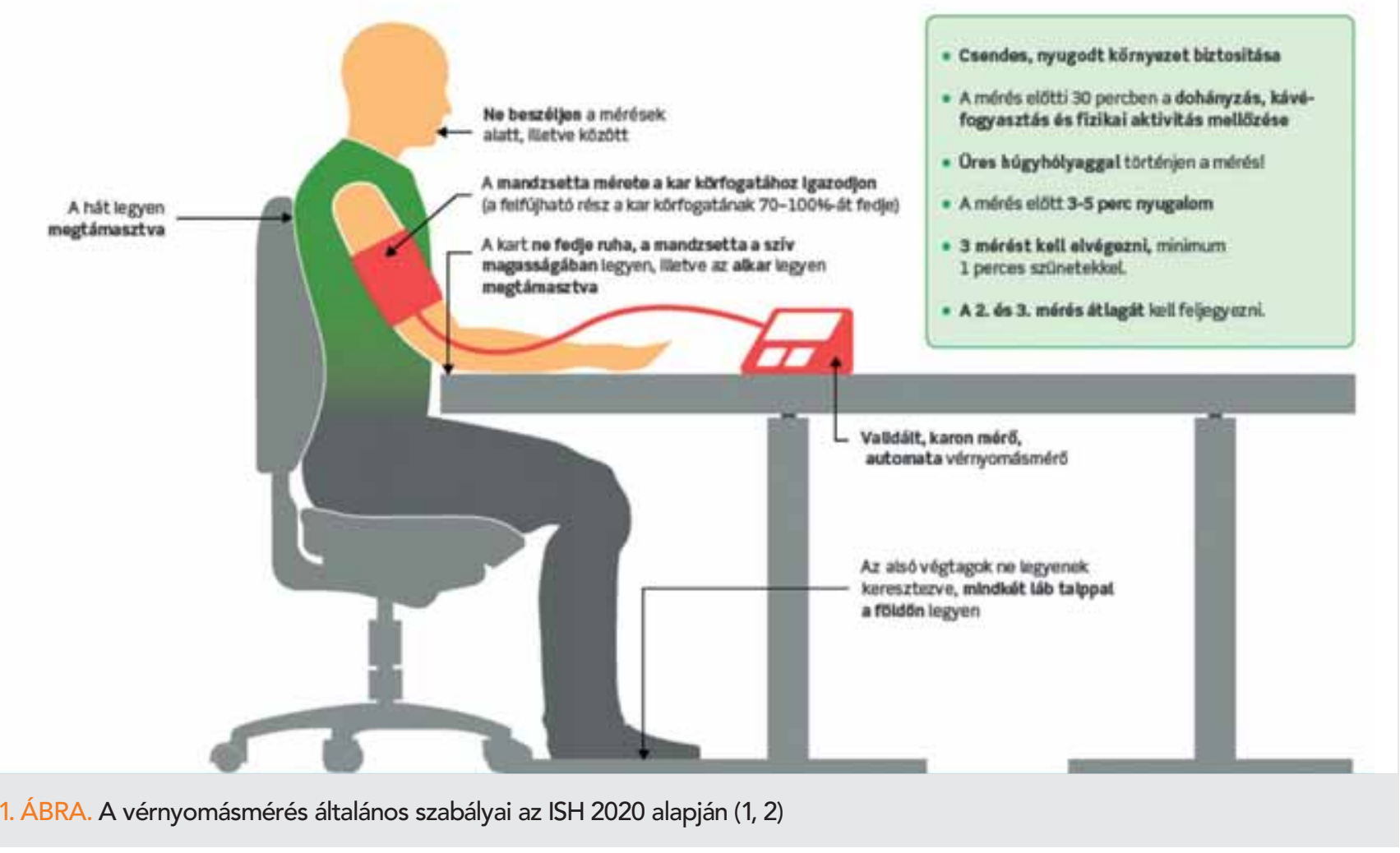

ABPM-vizsgálat. Az utóbbi két technika során kapott értékek ugyanis jobban reprodukálhatók, mint a rendelői mérések, szorosabban kapcsolódnak a hipertónia okozta szervkárosodásokhoz és a CV-események kockázatához, valamint azonosítják a fehérköpeny- és rejtett hipertóniát.

A hipertónia diagnosztikai algoritmusát a 2. ábra mutatja be.

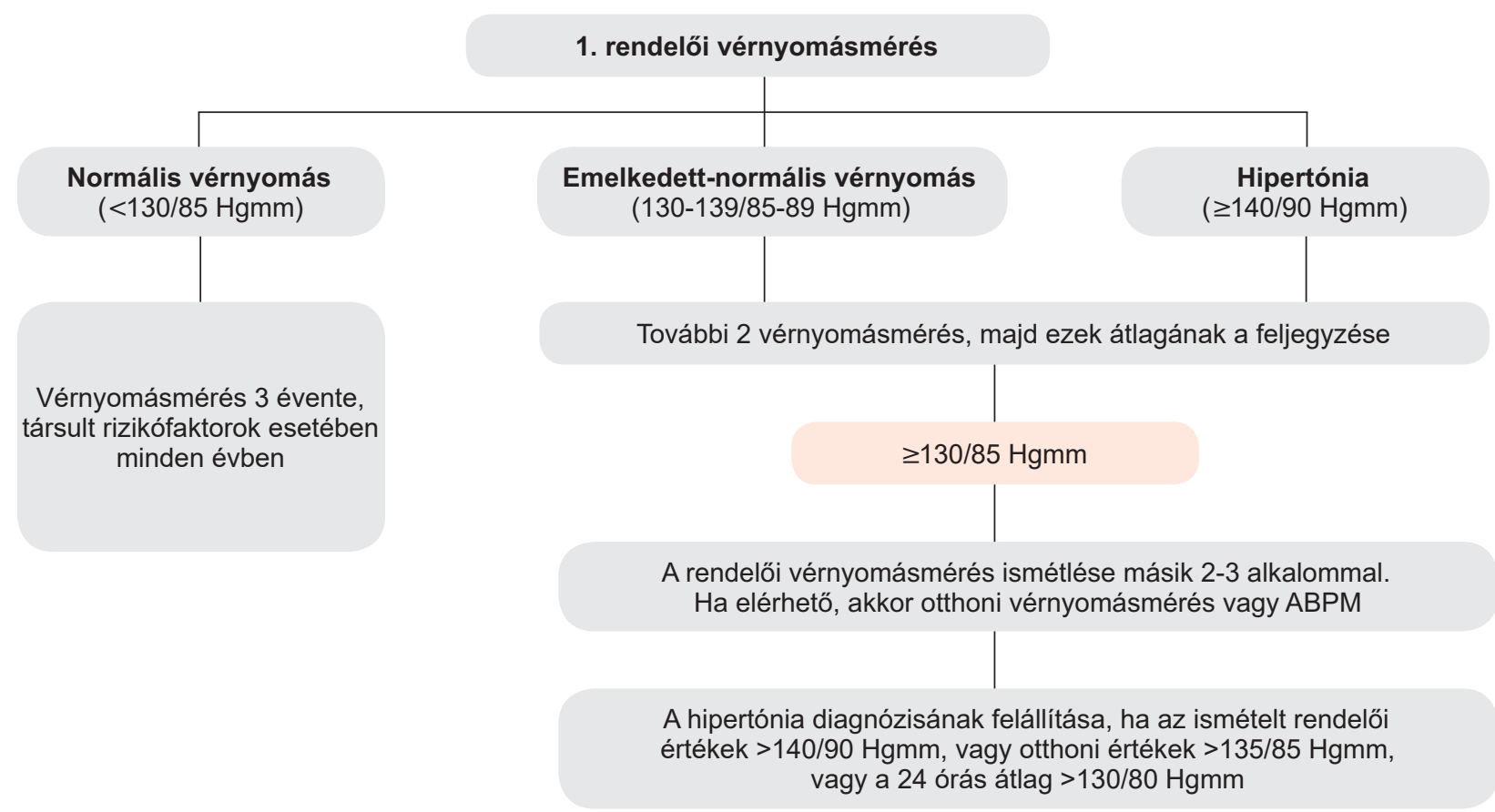

2. ÁBRA. A hipertónia diagnosztikai algoritmusa az ISH 2020 alapján 
2. TÁBLÁZAT. Hipertóniát provokáló gyógyszer/egyéb anyagok okozta mellékhatások

Gyógyszer/egyéb anyag
$\begin{aligned} & \text { Nem szteroid } \\ & \text { gyulladáscsökkentők (NSAID) }\end{aligned}$
$\begin{aligned} & \text { Kombinált per os } \\ & \text { fogamzásgátlók }\end{aligned}$
Antidepresszánsok
Acetaminofen
Egyéb gyógyszerek, amelyek
emelik a vérnyomást

Füszerek, egyéb anyagok

\section{Megjegyzések}

Celecoxib és az egyéb nem szelektív NSAID-ok +3/1 Hgmm vérnyomás-emelkedést okozhatnak (acetilszalicilsav nem okoz vérnyomás-emelkedést), NSAID-ok antagonizálhatják a RAAS-gátlók és a béta-blokkolók hatását

+6/3 Hgmm vérnyomás-emelkedést okozhatnak a nagy dózisú ösztrogéntartalmú készítmények (>50 $\mu \mathrm{g}$ ösztrogén, $1-4 \mu \mathrm{g}$ progeszteron)

+2/1 Hgmm vérnyomás-emelkedést okozhat az SNRI (szelektív norepinefrin és szerotonin-újrafelvétel-gátló) kezelés. A hipertónia kockázata 3,19\%-kal nő triciklikus antidepresszánssal kezelés során. Az SSRI (szelektív szerotonin-visszavétel-gátló) kezelés nem növeli a vérnyomást.

Napi szedése 1,34-szeresére növeli a hipertónia kockázatát

Szteroidok, antiretrovirális terápia (inkonzisztens vizsgálat szerint nőhet a vérnyomás), szimpatomimetikumok (pszeudoefedrin, kokain, amfetaminok), migrénellenes szerotoninerg szerek rekombináns humán eritropoetin, kalcineurin-gátlók, antiangiogenezis- és kinázgátlók, 11 ß-hidroxiszteroid-dehidrogenáz enzim T2-gátlószere

Alkohol, csikófarokmag (ma-huang gyógyfü), nagy adag ginzeng, édesgyökér, orbáncfü, yohimbin

\section{Kivizsgálás \\ Alapvető}

Pontos saját és családi anamnézis felvétele és fizikális vizsgálat szükséges az egyéni kockázat nagyságának becslése érdekében, a gyógyszerek okozta (hipertóniát provokáló) mellékhatások felismerése (2. táblázat), a hipertónia okozta szervkárosodások (HMOD), valamint a szekunder hipertónia kizárása céljából. Laborvizsgálatok: nátrium, kálium, szérumkreatinin, eGFR, hasznos a lipidprofil és az éhomi vércukor, vizeletfehérje szürőpapírcsíkkal. 12 elvezetéses EKG (ritmuszavar, LVH és hypoxiás jelek).

\section{Optimális}

Echokardiográfia, nyaki nagyerek ultrahang (UH) vizsgálata, vesék, veseartériák és mellékvesék képalkotó vizsgálata (UH, CT-, MR-angio). Boka-kar index, szekunder hipertónia kizárása (aldoszteron/renin arány, vizelet metanefrinek, kortizol, TSH stb.), vizeletalbumin/ kreatinin arány, szérumhúgysav, májfunkció.

A hipertóniás betegek több mint $50 \%$-án további CV kockázati tényező is felismerhető.

Leggyakoribbak: cukorbetegség (15-20\%), lipidrendellenességek $(30 \%)$, túlsúly/elhízás $(40 \%)$, hyperurikaemia $(25 \%)$, metabolikus szindróma (40\%), valamint egészségtelen életmódi szokások (pl. dohányzás, túlzott alkoholfogyasztás, ülő életmód stb.). Ezért hipertóniában a mindenki által kötelezően ismert ESC-ESH-iránymutatás szerint (3) fel kell mérni a teljes CV-kockázatot a világ bármely táján. Érdekes módon az ISH 2020. az európai hipertónia ajánlás CV-kockázatot felmérő táblázatára hivatkozik, de saját meghatározásának megfelelően az csak kétfokozatú hipertóniát tartalmaz.

A HMOD speciális tisztázása valószínüleg nem változtatja meg a nagy kockázatú betegek kezelését (ismert CV-betegség, diabétesz, vesebaj, dyslipidaemia stb.), mégis jellemző terápiás útmutatást nyújthat a kis, vagy közepes kockázatú betegek kezelésére és a HMOD- ban preferált gyógyszerek kiválasztására. Nyilvánvalóan a két legfontosabb károsodás, az albuminuria és a balkamra-hipertrófia mindenkori kizárására kell törekedni.

\section{Nem gyógyszeres kezelés}

A szegény országokban a nem gyógyszeres kezelési módszerek elterjesztése érthető módon alapvetően fontos. Az általánosan ismert módszereken (sószegény étrend, alkoholfogyasztás korlátozása, a dinamikus testmozgás fokozása, fogyás, DASH-diéta) túlmenően úttörő módon az ajánlás foglalkozik a stresszkerülő életmód és a meditáció vérnyomáscsökkentő hatásával. Javasolják az egészséges italok fogyasztását: mérsékelt mennyiségủ kávé, zöld és fekete tea; egyéb elönyös italok: hibiszkusztea, gránátalmalé, céklalé, kakaó. Javasolják a dohányzás abbahagyását és a dohányzás abbahagyására irányuló programok terjesztését. A tanulmányokból származó bizonyítékok szerint erőteljesen csökkenteni kellene a levegőszennyezésnek való kitettséget.

Végre kiemelésre került a komplementer, alternatív és tradicionális orvoslás hatástalansága, pedig Afrikában és Kínában a hipertóniások nagy hányada kiegészítő, alternatív vagy hagyományos gyógyszereket és módszereket használ.

Meg kell végül jegyezni, hogy az európai ajánlás a dinamikus/aerob fizikai aktivitást preferálja, az ISH 2020 megengedi az alkalmi ellenállás-edzéseket is.

\section{A gyógyszeres kezelés algoritmusa}

100 ország adatait feldolgozva, nagy vonalakban állítható az, hogy a hipertóniások valamivel kevesebb, mint $50 \%$-a kap vérnyomáscsökkentő kezelést, pedig már 20/10 Hgmm-es vérnyomáscsökkenés is mintegy $50 \%$ kal kisebb CV-kockázattal jár $(6,7)$ ! 
A kezelés megkezdésének alapelve megegyezik az ESC/ESH 2018. ajánláséval, vagyis nagy kockázatú 1. fokozatú, valamint bármely 2. fokozatú hipertóniában azonnali gyógyszeres kezelés szükséges, de 1. fokozatban kis CV-kockázat esetén akár 3-6 hónapon keresztül van lehetőség a nem gyógyszeres kezelés önálló alkalmazására. A célvérnyomást illetően az ajánlás elődeivel megegyezően alacsonyabb értékek bevezetését javasolja, azaz erőteljes, de óvatos vérnyomáscsökkentést.

\section{Alapvetó}

Célvérnyomás: legalább 20/10 Hgmm-es csökkentés, ideálisan <140/90 Hgmm.

\section{Optimális}

Célvérnyomás <65 év: <130/80 Hgmm, ha tolerálja a beteg (de >120/70 Hgmm), $\geq 65$ év: <140/90 Hgmm, de eközben mindig mérlegelni kell az egyéni (különösen az „esendő”) állapotot és a kezelés várható tolerálhatóságát.

A legtöbb beteg esetén a vérnyomáscsökkentő kezelés megkezdése két gyógyszer, kombinációjával javasolt. Ha a kettős és hármas (fix) kombinációk elérhetők, akkor már a 2. lépéstől kezdve könnyen megvalósítható az egyénre szabott antihipertenzív terápia a különféle dóziskombinációk alkalmazásával. Ez megfelelő gyógyszerválaszték esetén előnyös, és elég nagy ru- galmasságot biztosít az orvosok számára. Az algoritmust a 3. ábra tartalmazza.

A mindennapi gyakorlatra vonatkozóan több érdekes és fontos részletet kell kiemelni:

- a „kis dózis” általánosságban a maximális ajánlott dózis felét jelenti,

- a diuretikumok közül a tiazidszerü diuretikum a javasolt választás (Magyarországon ebből a csoportból az indapamidot forgalmazzák),

- terápiarezisztens hipertóniában felsorolt gyógyszerek a spironolaktonon kívül: amilorid, doxasosin, eplerenon, clonidin, bétareceptor-blokkoló,

- a randomizált, kontrollált tanulmányok eredményei alapján az ACE-gátlók és az ARB-k hasznossága nem egyezik meg minden esetben az eltérő betegpopulációkban, ezért a renin-angiotenzin rendszer e két gátlószere közötti választást mindig a beteg jellemzői, a készítmény elérhetősége, költsége, valamint tolerálhatósága határozza meg,

- a gyógyszerválasztás alapvetően individuális (a beteg állapotának megfelelő ideális kezelés igénye!), ám elsősorban a szegényebb országokra vonatkozóan, ha a fix kombinációs készítmény nem hozzáférhető, akkor természetesen az azonos hatóanyagú szabad kombináció alkalmazandó,

- amennyiben nem áll rendelkezésre tiazidszerü diuretikum, akkor adható tiazid,
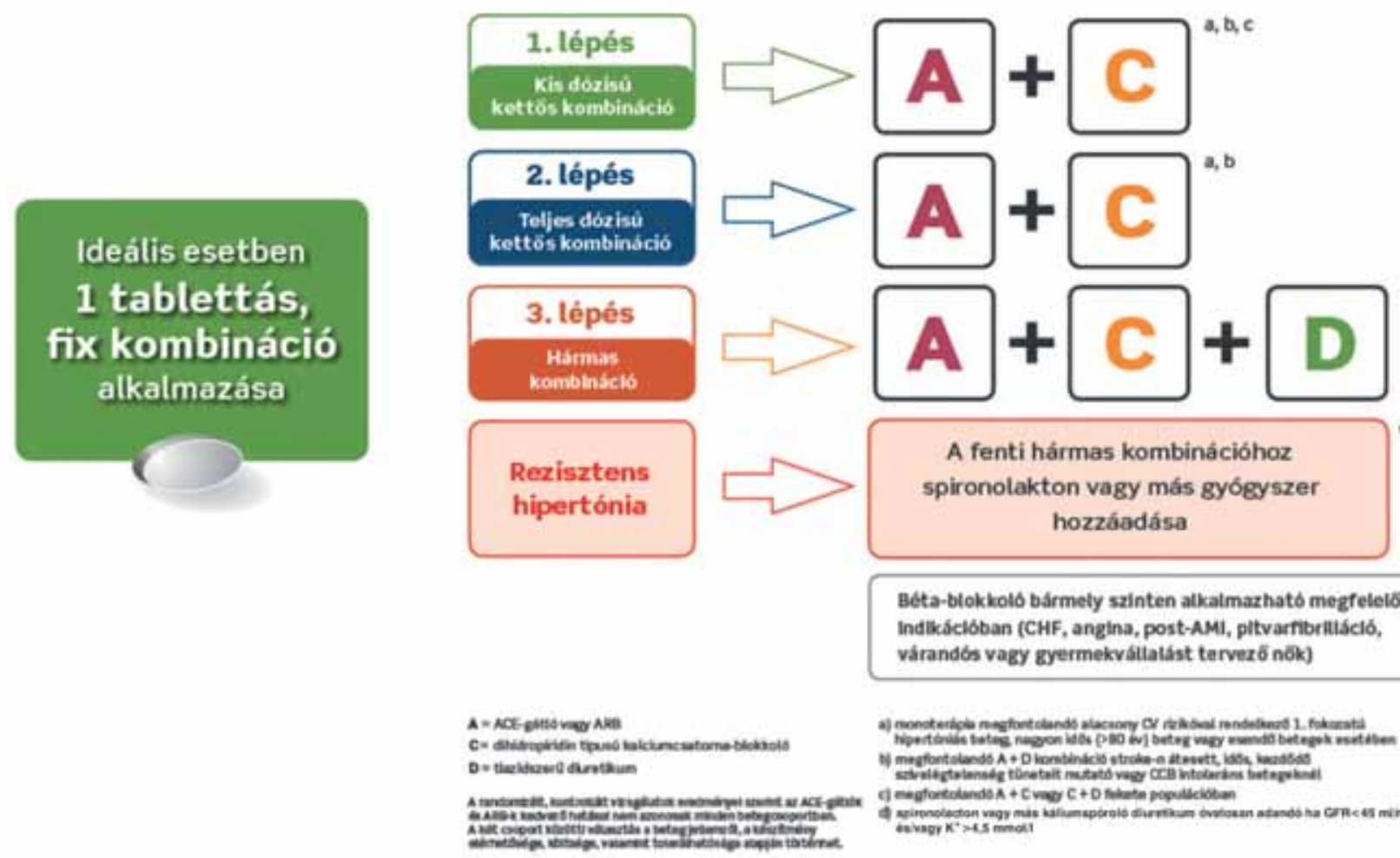

A fenti hármas kombinációhoz spironolakton vagy más gyógyszer hozzáadása

Beta-blokkolo barmely szinten alkalmazhato megfelelo Indiḱdeloban (CHF, angina, post-AMI, pltvarnbeillíścí, várandbs vagy gyermekvállatíst terverố nok]

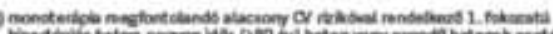

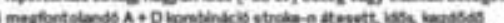

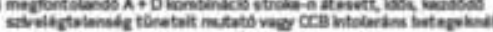

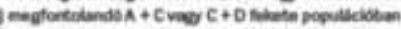

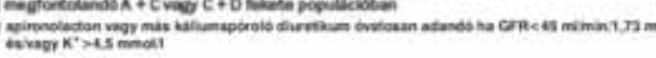

3. ÁBRA. A gyógyszeres terápiára vonatkozó algoritmus-komplikációktól mentes hipertóniában az ISH 2020 alapján (A: ACE-gátló - angiotenzin-konvertáló-enzim-gátló, vagy ARB - angiotenzinreceptor-blokkoló; C: CCB - kalciumcsatorna-blokkoló; D: tiazidszerú diuretikum; CHF: szívelégtelenség, AMl: szívinfarktus) 
- ha nem elérhető, vagy nem tolerálható a dihidropiridin CCB, akkor kipróbálható a nondihidropiridin CCB.

Elismerve azt, hogy a kezelés felépítése az ESC/ESH 2018 ajánlásnál jóval rugalmasabb, az ISH 2020 gyógyszeres terápiára vonatkozó algoritmusával kapcsolatosan mégis három megjegyzést teszek:

1. amennyiben megfelelő dózisválaszték áll rendelkezésre, akkor nem a maximális dózis felével kell elkezdeni a kezelést, hanem a minimálisan hatékony adaggal,

2. a következő lépés a célvérnyomás elérése érdekében ismét az individuálisan hatékony és nem a maximális dózisra való emelés,

3. a hatékonyság/tolerancia értékelése alapján nem a maximális dózisú kettős kombináció elérésére kell törekedni, hanem meg kell fontolni a minimálisan hatékony dózisú hármas kombináció bevezetését.

\section{Az adherencia javítása}

Nagyon hangsúlyos (végre) a beteg együttmüködésének tárgyalása. Az együttmüködés számos tényezőtől függ: következetes gyógyszerszedés, étrend betartása, életmód megváltoztatásának betartása, az egészségügyi szolgáltató állásfoglalása az ajánlásokról, a betegek társadalmi-gazdasági helyzete, forgalomban levő gyógyszerválaszték, 24 órás gyógyszerhatás, mellékhatások stb. A vérnyomáscsökkentő kezelés mellőzése (nonadherencia a nem gyógyszeres és gyógyszeres kezelés előírásaihoz), sajnos a hipertóniás betegek 10-80\%-át érinti, és a szuboptimális vérnyomáskontroll egyik fő mozgatórugója, ráadásul a rossz prognózis mutatója.

A gyógyszeres kezelés ideális, adherenciát erősítő tulajdonságai:

- a gyógyszerválasztásnak a morbiditás és mortalitás megelőzésével kapcsolatban bizonyítékokon kell alapulnia,

- 24 órán keresztül kitartó, hatékony gyógyszereket kell választani, a túlzott tablettaszám csökkentése érdekében fix kombinációk formájában,

- a választott kezelést jól kell tolerálni,

- a kezelésnek megfizethetőnek, valamint költséghatékonynak kell lennie,

- a gyógyszerbevételt (hogy ne felejtődjék el) a napi rutin szokásokhoz kell kötni,

- a betegeket be kell vonni a terápiás döntésekbe, amelyhez a legfontosabb az önvérnyomásmérés megtanulása és alkalmazása, vérnyomásnapló vezetése és annak értékelése,

- az adherenciát támogató elektronikus mobilalkalmazások, és az internet használata, ezek segítségével, valamint a csomagoláson is emlékeztető a gyógyszerbevételre,
- multidiszciplináris támogató csapat (nővérek-gyógyszerészek-gyógytornászok-dietetikusok) bevonása, - a felsoroltak alapján pontosan vissza kell jelezni a betegnek az adherenciát,

- elsősorban a gazdag országokban megvalósítható, ma még futurisztikus, vagyis kiemelten optimális a gyógyszertárak nyilvántartó rendszereinek ellenőrzése, tabletták számlálása, elektronikus gyógyszeradagolók használata stb.

Az ISH 2020 természetesen még számos fejezetből áll, ezek általánosságban harmonizálnak a két nagy (észak-amerikai és európai) hipertónia-vezérfonal hasonló fejezeteivel $(3,4)$, de több egyéni és hasznos megközelítést tartalmaznak, ezért szívből ajánlom mindenkinek részletes megismerésüket.

\section{Lehetséges érdekbeli ütközések számbavétele}

A közzétett dolgozat megjelenését az Egis Gyógyszer Zrt. támogatta. A dolgozat megállapításai új ismereteket tartalmaznak. Az ajánlással és a szereplö gyógyszerekkel kapcsolatosan a szerzőnek pénzügyi érdekeltsége nincs.

\section{Irodalom}

1. Unger T, Borghi C, Charchar F, et al. 2020 International Society of Hypertension Global Hypertension Practice Guidelines. Hypertension 2020; 75: 1334-1357. doi: 10.1161/HYPERTENSIONAHA.120.15026. Epub 2020 May 6

2. Unger T, Borghi C, Charchar F, et al. 2020 International Society of Hypertension global hypertension practice guidelines. J Hypertens 2020; 38: 982-1004. doi: 10.1097/HJH.0000000000002453

3. Williams B, Mancia G, Spiering W, et al. ESC Scientific Document Group. 2018 ESC/ESH Guidelines for the management of arterial hypertension. Eur Heart J 2018; 39: 3021-3104. doi: 10.1093/eurheartj/ehy339

4. Whelton PK, Carey RM, Aronow WS, et al. 2017 ACC/AHA/AAPA/ ABC/ACPM/AGS/APhA/ASH/ASPC/NMA/PCNA Guideline for the Prevention, Detection, Evaluation, and Management of High Blood Pressure in Adults: Executive Summary: A Report of the American College of Cardiology/American Heart Association Task Force on Clinical Practice Guidelines. Hypertension 2018; 71: 1269-1324. doi: 10.1161/HYP.0000000000000066. Epub 2017 Nov 13

5. Mills KT, Bundy JD, Kelly TN, et al. Global Disparities of Hypertension Prevalence and Control: A Systematic Analysis of PopulationBased Studies From 90 Countries. Circulation. 2016; 134: 441-450. doi: 10.1161/CIRCULATIONAHA.115.018912

6. NCD Risk Factor Collaboration (NCD-RisC). Long-term and recent trends in hypertension awareness, treatment, and control in 12 high-income countries: an analysis of 123 nationally representative surveys. Lancet 2019; 394: 639-651. doi: 10.1016/S01406736(19)31145-6. Epub 2019 Jul 18

7. Lewington S, Clarke R, Qizilbash $\mathrm{N}$, et al. Age-specific relevance of usual blood pressure to vascular mortality: a metaanalysis of individual data for one million adults in 61 prospective studies. Lancet 2002; 360: 1903-1913. doi: 10.1016/s01406736(02)11911-8 